\title{
EFFECT OF L-TYROSINE ORAL ADMINISTRATION TO GROWING OSSIMI LAMBS
}

\author{
MOHAMED Y. M. ${ }^{2}$, SAFAA N. ABDEL AZEEM ${ }^{2}$, A. K. I. KHAIRY ${ }^{1}$, \\ M. G. KHALIL GABR ${ }^{2}$, M. A. A. EL-BARODY ${ }^{1}$ AND A. A. ABD EL-HAKEAM ${ }^{1}$ \\ 1 Faculty of Agriculture, Minia University \\ 2 Animal Production Research Institute, ARC, Ministry of Agricultural, Doki-Giza
}

(Manuscript received 26 June 2011)

\begin{abstract}
The objective of this study was to determine the effect of Ltyrosine oral administration (100 mg/kg B.W.) on growing lambs performance from weaning till puberty. Growth performance till sexual activity, testes circumference, urethral process length, semen characteristics, testosterone and thyroid hormones levels were recorded. Thirty-two ram lambs and ewe- lambs were randomly divided into two equal groups, the first group $(n=8 \hat{0} \& 8$ \% $)$ was treated by L-tyrosine, and the second group $(n=8 \hat{0} \& 8$ \% $)$ was untreated and served as control. These animals were born in the lambing season of autumn (September/October 2007).

Ewe-and ram-lambs were weighed monthly. The ewe-lambs were kept with the ram lambs during the experimental period. Blood samples were collected at $0,6,8$ and 10 months post-weaning from ram-lambs to determine levels of testosterone, triiodothyronine (T3) and thyroxine (T4) hormones concentrations in plasma. Also, blood samples were collected at the same time from ewe-lambs to determine levels of $\mathrm{T} 3$ and $\mathrm{T} 4$.

The results revealed that lambs treated with L-tyrosine attained puberty at younger ages and heavier body weights compared to the untreated ones. Total gain and daily gain in both ram-and ewe lambs were increased significantly in treated lambs compared to the control. Triiodothyronine (T3) concentration was increased significantly $(P<0.05)$, while, thyroxine $(T 4)$ concentration was increased insignificantly in blood plasma by administration of Ltyrosine. Also, thyroid hormones concentrations were increased significantly $(P<0.01)$ by progressing in age until they reached the highest concentrations at ten months old. Moreover, testes circumference and urethral process length were insignificantly increased, but, libido was improved significantly $(P<0.01)$ in treated ram- lambs compared to the control group. Testosterone hormone concentration was increased significantly $(P<0.05)$ in treated ramlambs compared with the control group. Most of the physical semen properties were improved significantly $(P<0.01)$ in treated ramlambs. Finally, L-tyrosine oral treatment was accompanied with better economic returns.
\end{abstract}

\section{INTRODUCTION}

The sexual behaviour of females is synchronized by the ovarian activity (Hafez, 1987), as presence of developing follicles in the ovaries results in secretion of 
estrogen, yet, heat signs in females. It has been found that tyrosine, which helps in synthesis of the cerebral catecholamine was shown to activate the hypothalamus to release $\mathrm{GnRH}$, which stimulates pituitary gland to secrete gonadotrophins (FSH and LH) that activate the ovaries (Arthur, 1989).

El-Battawy (2006) studied the impact of melatonin or L-tyrosine administration on the onset of cycling in delayed pubertal ewe-lambs. The results concluded that the oral administration of melatonin or L-tyrosine played essential physiological roles to induce cycling in delayed pubertal ewe-lambs and improved their reproduction.

The purpose of the present study was to evaluate the effectiveness of Ltyrosine oral administration on growth performance and puberty of both ewe -and ram- lambs.

\section{MATERIALS AND METHODS}

The present study aimed to evaluate the effect of oral administration of Alpha-amino-p-hydroxyhydrocinnamic acid (L-tyrosine) on growth performance and puberty of both ram-and ewe- lambs. These animals were born in autumn lambing season (September/October 2007) and used in this trial. Each ram or ewe- lamb was given monthly, until puberty, a single oral dose of L-tyrosine at the level of $100 \mathrm{mg} / \mathrm{kg}$ b.w. dissolved in 200ml water (Kamel, 1996, El-Battawy, 2006). Finally, an economical evaluation of using this material was managed.

\section{Ram lambs}

Sixteen ram lambs weighed $22.5 \pm 0.65 \mathrm{~kg}$ and aged 2.5 months each at the starting of the experiment were used. Animals were divided into two groups, the first, $(n=8)$ was treated with L-tyrosine, and the second, $(n=8)$ was untreated and served as control. Sexual beheaviour activity of ram-lambs was checked daily, early in the morning by introducing teaser ewe. The ram-lambs which showed erection and extrusion of the penis out of the sheath, were caught immediately and a smear of fluids secreted around the penile sheath was prepared for microscopic examination. The ram-lamb which produced sperm in the examined smears, was immediately trained for semen collection using an artificial vagina. One ejaculate/ram-lamb was collected to determine semen characteristics. The ram-lamb's ability to ejaculate in an artificial vagina was considered as a puberty criterion. The date of first ejaculation was recorded and the lambs were weighed. Testes circumference $(\mathrm{cm})$, sexual libido $(\mathrm{min})$ and urethral process length $(\mathrm{cm})$ were measured. 


\section{Ewe-lambs}

Sixteen Ossimi ewe- lambs weighed $19.75 \pm 0.82 \mathrm{~kg}$ and aged 2.5 months at the starting of the experiment, were used. Animals were divided into two equal groups, the first group $(n=8)$ was treated with L-tyrosine, and the second group $(n=8)$ was untreated with L-tyrosine and served as control. Estrus beheaviour of ewe- lambs was checked by active rams twice daily at 8 am and $4 \mathrm{pm}$. The lambs body weight and age were recorded when the first incidence of heat was observed,.

Growth rate was determined for ewe-and ram-lambs. The ewe-lambs were kept with the ram- lambs during the experimental period. This experiment was conducted during the period from January till September 2008. Blood samples were collected at weaning 6, 8 and 10 months post-weaning from ram -lambs to determine levels of testosterone, triiodothyronine (T3) and thyroxine (T4) hormone concentrations. Also, blood samples were collected at the same time from ewe- lambs to determine levels of T3 and T4. Testosterone levels were determined in plasma by the method of Jaffe and Behrman (1974) who performed the assessment of total testosterone concentration using Coat-A-count $\mathrm{I}^{125}$ radioimmunoassay (RIA) by using kits. Triiodothyronine (T3) and Thyroxine (T4) were determined by radiommunoassay procedures according to Chopra et. al. (1971), Irvin \& Standeven (1968), respectively by using kits.

Data were statistically analyzed according to the General Liner Model (GLM) of the SAS program (SAS, 1999) and the differences between means were detected by Duncan's Multiple Range Test (Duncan, 1955).

\section{RESULTS AND DISCUSSION}

The effect of L-tyrosine oral administration on some productive and reproductive performance of growing Ossimi ram-and ewe-lambs till puberty is presented in Table 1.

The present results show that the productive performance of both ewe and ram-lambs were improved as a result of L-tyrosine oral administration. Total gain and daily gain values were significantly $(P<0.05 \& P<0.01)$ increased in treated lambs compared to the control. Also, lambs pubertal weight and age in treated groups were significantly $(P<0.05)$ heavier and younger than those in untreated groups (control). The percentages of improvements were 65.52 and $41.86 \%$ in total gain, 95.74 and $62.71 \%$ in daily gain, 22.73 and $14.75 \%$ in body weights at puberty and 14.81 and $14.21 \%$ in age at puberty in-ram and ewe-lambs, respectively compared to control 
group (Table 1). It could be suggested that tyrosine acts as a growth promoting factor. Earlier reports showed that increasing the circulating tyrosine activates the hypothalamic catecholamine, dopamine, which in turn activates the release of growth hormone (Müller, 1973).

Table 1. Productive and reproductive performance of Ossimi ram and ewe-lambs as affected by L-tyrosine oral administration

\begin{tabular}{|c|c|c|c|c|c|c|c|c|c|c|c|}
\hline \multirow[b]{2}{*}{ Treatments } & \multirow[b]{2}{*}{$\begin{array}{l}\text { No. of } \\
\text { animals }\end{array}$} & \multicolumn{5}{|c|}{ Ram lambs (LSM $\pm \mathrm{SE})$} & \multicolumn{5}{|c|}{ Ewe-lambs (LSM \pm SE) } \\
\hline & & $\begin{array}{r}\text { Initial } \\
\text { weight } \\
(\mathrm{kg})\end{array}$ & $\begin{array}{c}\text { B.w. at } \\
\text { puberty } \\
(\mathrm{kg})\end{array}$ & $\begin{array}{l}\text { Total } \\
\text { gain } \\
(\mathrm{kg})\end{array}$ & $\begin{array}{l}\text { Daily } \\
\text { gain } \\
\text { (g) }\end{array}$ & $\begin{array}{l}\text { Age at } \\
\text { puberty } \\
\text { (days) }\end{array}$ & $\begin{array}{r}\text { Initial } \\
\text { weight } \\
(\mathrm{kg})\end{array}$ & $\begin{array}{c}\text { B.w. at } \\
\text { puberty } \\
(\mathrm{kg})\end{array}$ & $\begin{array}{l}\text { Total } \\
\text { gain } \\
(\mathrm{kg})\end{array}$ & $\begin{array}{c}\text { Daily } \\
\text { gain (g) }\end{array}$ & $\begin{array}{c}\text { Age at } \\
\text { puberty } \\
\text { (days) }\end{array}$ \\
\hline & & NS & * & * & $* *$ & * & NS & * & * & ** & * \\
\hline L-tyrosine & 16 & 22.88 & $42.50^{\mathrm{a}}$ & $19.63^{\mathrm{a}}$ & $79.04^{\mathrm{a}}$ & $259.13^{\mathrm{a}}$ & 19.75 & $35.00^{\mathrm{a}}$ & $15.25^{\mathrm{a}}$ & $62.35^{\mathrm{a}}$ & $248.13^{a}$ \\
\hline Control & 16 & 22.75 & $34.63^{b}$ & $11.88^{\mathrm{b}}$ & $40.38^{\mathrm{b}}$ & $297.50^{\mathrm{b}}$ & 19.75 & $30.50^{b}$ & $10.75^{b}$ & $38.32^{b}$ & $283.38^{\mathrm{b}}$ \\
\hline \multicolumn{2}{|c|}{$\pm \mathrm{SE}$} & 0.64 & 1.30 & 1.59 & 7.77 & 10.27 & 0.86 & 1.24 & 1.09 & 5.04 & 9.97 \\
\hline
\end{tabular}

$a, b$, Means in the same column under the same trait followed by the same superscript are not significantly different. NS $=$ Not significant, $*=(\mathrm{P}<0.05), * *=(\mathrm{P}<0.01)$.

The results of El-Battawy (2006) support these findings. The present results indicated that body weight at puberty of ewe-lambs was less than body weights of ram-lambs. At the same time, age at puberty of ram-was more than that of ewelambs. Also, Ferial et. al. (1992) reported that Ossimi ewe-lambs reached puberty at ages round $288.2 \pm 0.4$ day and weights $33.3 \pm 0.2 \mathrm{~kg}$, while, Ossimi ram lambs reached puberty at ages round $296.8 \pm 5.4$ days and weights $41.1 \pm 6.6 \mathrm{~kg}$.

Thyroid hormone levels in Ossimi growing lambs as affected by the oral administration of L-tyrosine are summarized in Tables $2 \& 3$. It was noticed that triiodothyronine (T3) was increased significantly $(P<0.05)$ in treated lambs, while, thyroxine (T4) was increased, but insignificant in treated lambs compared to the control ones. Additionally, post-treatment time had a positive effect on T3 and T4 concentrations. 
Table 2. Triiodothyronine (T3) level in Ossimi growing lambs as affected by the Ltyrosine oral administration

\begin{tabular}{|c|c|c|c|}
\hline \multirow{2}{*}{$\begin{array}{c}\text { Time } \\
\text { (months) }\end{array}$} & \multicolumn{2}{|c|}{ Treatments (LSM $\pm \mathrm{SE}$ ) } & \multirow{2}{*}{$\begin{array}{l}\text { Overall } \\
\text { means }\end{array}$} \\
\hline & L-tyrosine & Control & \\
\hline \multicolumn{4}{|c|}{ Ewe lambs } \\
\hline At weaning & $129.98 \pm 9.52$ & $124.29 \pm 9.52$ & $127.14 \pm 6.86^{b}$ \\
\hline 6 & $135.57 \pm 9.52$ & $125.24 \pm 9.52$ & $128.76 \pm 6.86^{b}$ \\
\hline 8 & $141.66 \pm 9.52$ & $128.47 \pm 9.52$ & $135.07 \pm 6.86^{b}$ \\
\hline 10 & $170.18 \pm 9.52$ & $151.30 \pm 9.52$ & $157.99 \pm 6.86^{a}$ \\
\hline Overall means & $142.98 \pm 4.85^{\mathrm{a}}$ & $131.50 \pm 4.85^{b}$ & $137.24 \pm 5.86$ \\
\hline \multicolumn{4}{|c|}{ Ram lambs } \\
\hline At weaning & $104.95 \pm 9.52$ & $101.20 \pm 9.52$ & $103.07 \pm 6.61^{c}$ \\
\hline 6 & $130.30 \pm 9.52$ & $121.94 \pm 9.52$ & $127.77 \pm 6.61^{b}$ \\
\hline 8 & $140.22 \pm 9.52$ & $125.64 \pm 9.52$ & $132.93 \pm 6.61^{b}$ \\
\hline 10 & $164.69 \pm 9.52$ & $145.16 \pm 9.52$ & $157.67 \pm 6.61^{a}$ \\
\hline Overall means & $136.41 \pm 4.67^{a}$ & $124.31 \pm 4.67^{b}$ & $130.36 \pm 5.64$ \\
\hline
\end{tabular}

$a-c$, overall means in the same columns and rows followed by the same superscript are not significantly different.

Table 3. Thyroxine (T4) level in Ossimi growing lambs as affected by the L-tyrosine oral administration

\begin{tabular}{|c|c|c|c|}
\hline \multirow{2}{*}{$\begin{array}{c}\text { Time } \\
\text { (months) }\end{array}$} & Treatments (LSM \pm SE) & \multirow{2}{*}{$\begin{array}{c}\text { Overall } \\
\text { means }\end{array}$} \\
\cline { 2 - 3 } & \multicolumn{3}{|c|}{ Ewe lambs } \\
\hline \multicolumn{4}{|c|}{ Control } \\
\hline At weaning & $3.73 \pm 1.02$ & $3.51 \pm 1.02$ & $2.15 \pm 0.73^{\mathrm{b}}$ \\
6 & $4.17 \pm 1.02$ & $3.57 \pm 1.02$ & $3.37 \pm 0.73^{\mathrm{ab}}$ \\
8 & $4.23 \pm 1.02$ & $4.03 \pm 1.02$ & $4.07 \pm 0.73^{\mathrm{ab}}$ \\
10 & $7.80 \pm 1.02$ & $5.92 \pm 1.02$ & $5.61 \pm 0.73^{\mathrm{a}}$ \\
\hline Overall means & $4.19 \pm 0.51$ & $3.41 \pm 0.51$ & $3.80 \pm 0.62$ \\
\hline \multicolumn{3}{|c|}{ Ram lambs } \\
\hline At weaning & $2.28 \pm 1.02$ & $2.02 \pm 1.02$ & $3.65 \pm 0.72^{\mathrm{b}}$ \\
6 & $3.97 \pm 1.02$ & $2.57 \pm 1.02$ & $3.74 \pm 0.72^{\mathrm{b}}$ \\
8 & $4.11 \pm 1.02$ & $3.46 \pm 1.02$ & $3.84 \pm 0.72^{\mathrm{b}}$ \\
10 & $6.21 \pm 1.02$ & $5.01 \pm 1.02$ & $6.86 \pm 0.72^{\mathrm{a}}$ \\
\hline Overall means & $4.93 \pm 0.51$ & $4.12 \pm 0.51$ & $4.53 \pm 0.61$ \\
\hline
\end{tabular}

$\mathrm{a}, \mathrm{b}$, overall means in the same columns and rows followed by the same superscript are not significantly different.

The present results indicated the importance of L-tyrosine administration in formation of thyroxine and protein synthesis. Harper et. al. (1980) reported that L- 
tyrosine is utilized by the thyroid gland for the production of thyroxine which is considered a vital hormone involved in regulating growth, metabolism, skin health and mental state. The improvement in growth rate and enhancement of puberty in both ram-and ewe-lambs could be reported as due to increasing the secretions of T3 and T4. Thyroid activity was positively related to growth rate in sheep (Lovell et. al., 1987). Additionally, the thyroid hormones play an important role in regulating the process of growth, lactation, reproduction and general health (Jainudeen et. al., 2000).

The reproductive traits and testosterone level of Ossimi ram lambs treated with L-tyrosine and control group are summarized in Tables 4\&5. The results illustrated that, testes circumference and urethral process length were insignificantly increased, but, libido was significantly ( $P>0.01)$ improved in treated group compared to control group. Table 4 showed also that, control ram-lambs reached their first ejaculation at older age, while they still had lighter weight $(P<0.05)$, which is due to slower growth rate (Table 1) compared to the treated ram lambs.

Table 4. Some reproductive traits of Ossimi ram-lambs at puberty as affected by Ltyrosine oral administration

\begin{tabular}{|c|c|c|c|c|c|c|}
\hline \multirow[b]{2}{*}{ Treatments } & \multirow[b]{2}{*}{$\begin{array}{l}\text { No. of } \\
\text { lambs }\end{array}$} & \multicolumn{5}{|c|}{ Reproductive traits (LSM $\pm \mathrm{SE}$ ) } \\
\hline & & $\begin{array}{c}\text { Testes } \\
\text { circumferenc } \\
\text { e }(\mathrm{cm}) \\
\end{array}$ & $\begin{array}{c}\text { Urethral } \\
\text { process } \\
(\mathrm{cm})\end{array}$ & $\begin{array}{l}\text { Libido } \\
\text { (min) }\end{array}$ & $\begin{array}{l}\text { Body weight } \\
\text { at puberty } \\
(\mathrm{kg})\end{array}$ & $\begin{array}{l}\text { Age at } \\
\text { puberty } \\
\text { (day) }\end{array}$ \\
\hline & & NS & NS & ** & $*$ & $*$ \\
\hline L-tyrosine & 8 & 21.50 & 1.34 & $15.63^{a}$ & $35.63^{\mathrm{a}}$ & $259.13^{a}$ \\
\hline Control & 8 & 19.38 & 1.11 & $18.75^{b}$ & $30.50^{\mathrm{b}}$ & $297.50^{\mathrm{b}}$ \\
\hline$\pm \mathrm{SE}$ & & 0.80 & 0.09 & 0.89 & 1.30 & 10.27 \\
\hline
\end{tabular}

$\mathrm{a}, \mathrm{b}$, Means in the same column followed by the same superscript are not significantly different. NS $=$ Not significant $, *=(P<0.05), * *=(P<0.01)$. 
Table 5. Testosterone level of Ossimi ram-lambs as affected by L-tyrosine oral administration and different time post-treatment

\begin{tabular}{|c|c|c|c|}
\hline \multirow{2}{*}{$\begin{array}{c}\text { Time } \\
\text { (months) }\end{array}$} & \multicolumn{2}{|c|}{ Treatments (LSM $\pm \mathrm{SE})$} & \multirow{2}{*}{$\begin{array}{l}\text { Overall } \\
\text { Means }\end{array}$} \\
\hline & Treated & Control & \\
\hline At weaning & $131.87 \pm 48.55$ & $72.71 \pm 48.55$ & $102.30 \pm 34.33^{b}$ \\
\hline 6 & $174.50 \pm 48.55$ & $110.75 \pm 48.55$ & $142.63 \pm 34.33^{b}$ \\
\hline 8 & $255.69 \pm 48.55$ & $145.44 \pm 48.55$ & $200.56 \pm 34.33^{a}$ \\
\hline 10 & $298.98 \pm 48.55$ & $192.04 \pm 48.55$ & $245.51 \pm 34.33^{\mathrm{a}}$ \\
\hline Overall means & $215.26 \pm 24.28^{\mathrm{a}}$ & $130.24 \pm 24.28^{\mathrm{b}}$ & $172.75 \pm 2931$ \\
\hline
\end{tabular}

a, b , overall means in the same columns and rows followed by the same superscript are not significantly different.

Results in Table 5 show that the overall mean of testosterone level was significantly $(P<0.05)$ higher for treated ram- lambs compared with the control. Advance of time (month) post-treatment led to significant $(P<0.01)$ increase in testosterone concentration level as a result of continual monthly oral administration of L-tyrosine (102 \pm 34.33 at zero time to $245.51 \pm 34.33$ at 10 months of treatment). Ltyrosine might induce early puberty in male sheep (El-Battawy, 2006). In addition, Ltyrosine was considered as a growth promoting factor and led to stimulate the gonadotrophin releasing factor, which potentiates the testicular function (Kamberi et al., 1971, Müller, 1973).

The sexual behaviour of females is synchronized by the ovarian activity (Hafez, 1987), since presence of developing follicles in the ovaries is followed by secretion of estrogen which results in standing female position to be mated by the male. This supports the hypothesis that tyrosine has a function on the synthesis of cerebral catecholamine and led to activate the hypothalamus to release GnRH (Hammerl and Rüsse, 1987 and Arthur, 1989).

Table 6 illustrates that treated ram-lambs showed significant improvement in most semen characteristics. Also, the results indicated that there were insignificant differences between first and second ejaculates in all physical semen characteristics studied. The amounts of improvement in semen characteristics due to L-tyrosine oral administration, were $36.11 \%$ in semen motility, $64.29 \%$ in sperm concentration /Ejc, and $102 \%$ in motile sperm /Ejc compared to the control. 
Table 6. Some physical semen characteristics of Ossimi ram lambs at puberty as affected by L-tyrosine oral administration and ejaculate sequence

\begin{tabular}{|c|c|c|c|c|c|c|c|}
\hline \multirow[b]{2}{*}{ Factors } & \multirow[b]{2}{*}{$\begin{array}{l}\text { No. of } \\
\text { samples }\end{array}$} & \multicolumn{6}{|c|}{ Semen characteristics } \\
\hline & & $\begin{array}{c}\text { Ejc. / Vol. } \\
(\mathrm{ml})\end{array}$ & $\begin{array}{c}\text { Motility } \\
(\%)\end{array}$ & $\begin{array}{c}\text { Conc. / } \\
\mathrm{ml} \mathrm{x} \\
10^{9} \\
\end{array}$ & $\begin{array}{l}\text { Sperm } \\
\text { output / } \\
\text { Ejc. }\left(10^{9}\right)\end{array}$ & $\begin{array}{l}\text { Motile } \\
\text { sperm / } \\
\mathrm{ml}\left(10^{9}\right)\end{array}$ & $\begin{array}{l}\text { Motile sperm } \\
\text { output/Ejc. }\end{array}$ \\
\hline$\underline{\text { Treatments }}$ & & * & $* *$ & $* *$ & $* *$ & $* *$ & $* *$ \\
\hline L-tyrosine & 8 & $0.75^{\mathrm{a}}$ & $61.25^{\mathrm{a}}$ & $2.13^{\mathrm{a}}$ & $1.61^{\mathrm{a}}$ & $1.30^{\mathrm{a}}$ & $0.99^{a}$ \\
\hline Control & 8 & $0.57^{b}$ & $45.00^{b}$ & $1.73^{\mathrm{b}}$ & $0.98^{\mathrm{b}}$ & $0.77^{\mathrm{b}}$ & $0.49^{b}$ \\
\hline$\pm \mathrm{SE}$ & & 0.05 & 3.24 & 0.09 & 0.12 & 0.07 & 0.09 \\
\hline Ejaculate & & & & & & & \\
\hline sequence & & Ns & Ns & Ns & Ns & Ns & Ns \\
\hline First & 16 & 0.66 & 50.00 & 1.90 & 1.26 & 0.96 & 0.69 \\
\hline Second & 16 & 0.67 & 56.25 & 1.96 & 1.38 & 1.11 & 0.79 \\
\hline$\pm \mathrm{SE}$ & & 0.05 & 3.24 & 0.09 & 0.12 & 0.07 & 0.09 \\
\hline
\end{tabular}

$\mathrm{a}, \mathrm{b}$, Means in the same column under the same factor followed by the same superscript are not significantly different. NS $=$ Not significant $(P>0.05), \quad *=(P<0.05), \quad * *=(P<0.01)$.

The present results are confirmed with those reported by El-Sayed et. al. (1992) who found that there was significant improvement in semen quality for rams treated with tyrosine administration. The ejaculate volume, the sperm concentration, the sperm motility and the sperm alive were significantly $(P<0.01)$ higher in the treated group than in the control. These differences may be due to the variations in testicular size (Ferial et. al., 1992). L-tyrosine caused a significant increase in semen volume which is correlated to increased sperm concentration. Increased sperm motility in consequence of treating males with L-tyrosine may be reflected on increased semen fructose concentration and increased live sperm percentage in the L-tyrosine treated groups compared to the control group (El-Sayed et. al., 1992).

Data in Table 7 indicated that the net revenue in both ram and ewe lambs recorded better return as a result of L-tyrosine oral administration compared to the control group. Improvement of economic gain in both ram-and ewe-lambs is due to increase of total body weight gain, and at the same time, decrease of total cost of these animals as a result of L-tyrosine oral administration. 
Table 7. Economical evaluation of L-tyrosine oral administration for Ossimi growing lambs.

\begin{tabular}{|c|c|c|c|c|}
\hline \multirow{2}{*}{ Items } & \multicolumn{2}{|c|}{ Ram-lambs } & \multicolumn{2}{|c|}{ Ewe lambs } \\
\hline & Ty & $\mathrm{CO}$ & Ty & $\mathrm{CO}$ \\
\hline Experimental period (day) & 169.13 & 207.50 & 158.13 & 193.38 \\
\hline Avg. feed consumed $(\mathrm{kg}) /$ day / lamb & 1.35 & 1.26 & 1.15 & 1.04 \\
\hline Total feed consumed $(\mathrm{kg}) /$ lamb till puberty & 228.33 & 261.45 & 181.85 & 201.12 \\
\hline Price of ration fed $(\mathrm{LE})^{1}$ & 285.41 & 326.81 & 227.31 & 251.39 \\
\hline $\begin{array}{l}\text { Avg. amount of L-tyrosine consumed }(\mathrm{g}) / \\
\text { lamb. }\end{array}$ & 16.29 & 0.00 & 6.06 & 0.00 \\
\hline Price of L-tyrosine consumed /lamb (LE) $)^{2}$ & 6.52 & 0.00 & 2.42 & 0.00 \\
\hline Total cost (LE) & 291.92 & 326.81 & 229.74 & 251.39 \\
\hline $\begin{array}{l}\text { Total body weight obtained up to puberty } \\
(\mathrm{kg})\end{array}$ & 42.50 & 34.63 & 35.00 & 30.50 \\
\hline Net revenue $(\mathrm{LE})^{3}$ & 558.08 & 365.79 & 470.26 & 358.61 \\
\hline
\end{tabular}

1, [Total feed consumed x 1.25 (price of one kg ration, LE)]

2. [Avg. amount of L-tyrosine consumed (g) $\times 0.4$ (price of one gm L-tyrosine, LE)]

3, [Total body weight $\times 20$ (price of one $\mathrm{kg}$ weight, LE)] - Total cost

Ty $=$ L-tyrosine treated,$\quad \mathrm{CO}=$ Control. 


\section{REFERENCES}

1. Arthur, Ri. 1989. Veterinary Reproduction and Obstetrics. (text book) Bailliere Tindall, London $6^{\text {th }}$ Edition.

2. Chopra, I. J., D. H. Solomon, and G. N. Beall. 1971. Radiommunoassay assay for measurement of Triiodothyronine in Human serum. J. Glin. Invest, 50: 2033.

3. Duncan, D. B. 1955. Multiple range and multiple F-tests. Biometrics, 11:1.

4. El-Battawy, K. A. 2006. Reproductive and endocrine characteristics of delayed pubertal ewe-lambs after melatonin and L-tyrosine administration. Reproductionin-Domestic-Animals, 41(1): 1-4.

5. El-Sayed, A. I., A. I. El-Azab and M. T. Nasr. 1992. Effect of oral administration of L-tyrosine on the quality of ram semen. Annals Agric. Sc., Moshtohor,. 30 (3): 1207.

6. Ferial, H.M., T. Mousa, A. M. Aboul-Naga, F. El-Hommosi and G. Abd El-Hafez. 1992. Puberty and early mating performance in subtropical fat-tailed sheep and their crosses. Proceedings of the Second, Biennial Conference of the African, Small ruminant research and development in Africa, Small Ruminant Research Network, AICC, Arusha, Tanzania7-11.

7. Hafez, E. S. E. 1987. Reproductive in farm animals (Text book). Lea and Febiger, Philadelphia, USA.

8. Harper, H. A., V. W. Rod-well and Mayes. 1980. Review of physiological chemistry $17^{\text {th }}$ Ed. Long Medical Publications, Middel East Edition, 265.

9. Irvin, W. J. and R. M. Standeven. 1968. Serum Triiodothyronine uptake using coated charcoal in the assessment of thyroid function. J. Endoc., 41: 31.

10. Jaffe, B. M. and N. A. Behrman. 1974. Methods of hormones radio-immunoassay (Academic press).

11. Jainudeen, M. R.H. Wahid and E.S.E.Hafez. 2000. Sheep and goats (text book). $7^{\text {th }}$ Ed. Reproduction in farm animals. In: Hafez E.S.E. and B. Hafez (Eds). Lippincott Williams and Wilkins, Philadelphia, USA. Pp: 172.

12. Kamberi, I. A. R. S. Mical and J. C. Porter. 1971. Effect of anterior pituitary infusion and intraventricular injection of catecholamines on prolactin release. Endocr., 88:1012.

13. Lovell, R. N. Gregory and D. Lister. 1987. Thyroid activity in relation to growth rate and body composition in four breeds of sheep. Vet. Res. Commun 11: 227233

14. Müller, E. E. 1973. Nervous control of growth hormone secretion. Neuroendocr., 11: 338-369.

15. S. A. S. 1999. Statistical Analysis System Guide. Version 6.12 Ed. SAS Institute Inc. Cary. NC, USA. 


\section{تأثثير تجريع التيروزين على أداء الحملان الأوسيمي النامية}

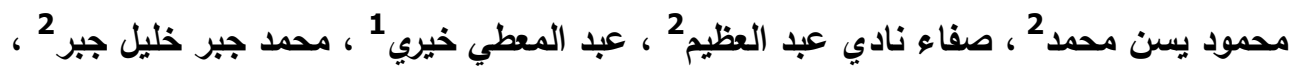

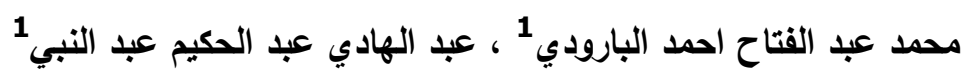

$$
\text { 1. معهُ بحوث الإنتاج الحيواني - مركز البحوث الزراعية - وزارة الزراعة- الدقى - الجيزة. }
$$

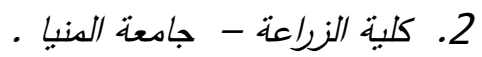

استهدفت هذه الدراسـة تحديد التأثنرات الايجابية لتجريع التيروزين (100 ملجم/ كجم وزن

حي) على أداء الحملان الأوسيمي النامية عقب الفطام وحتى البلوغ الجنسي. تم تسجيل وزن الحملان

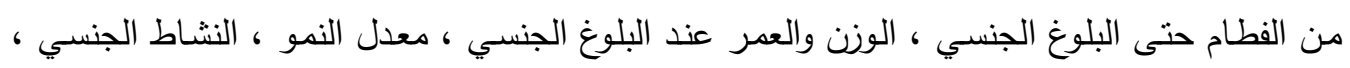
صفات السائل المنوي ، مستويات هرمون التستستيرون وكذلك هرمونات الغدة الدرقية. أستخدم في هذه وانه

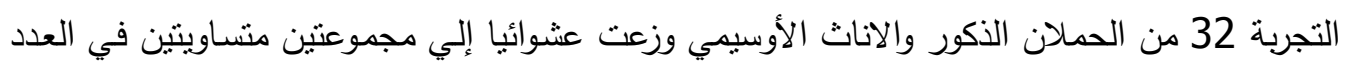

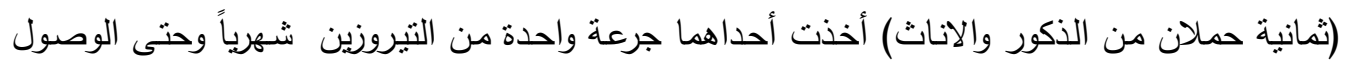

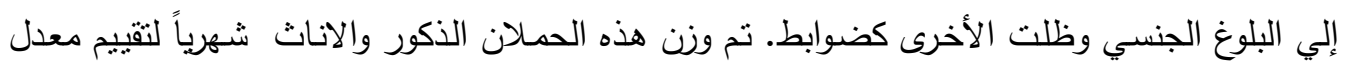

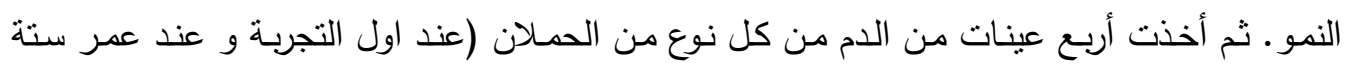

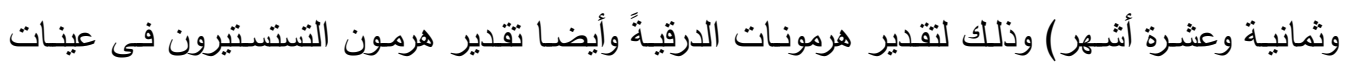

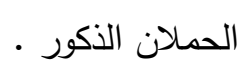

وأوضحت النتائج أن حملان الذكور والاناث المعاملة بالتيروزين قد بلغت إلى مرحلة البلوغ الجنسي عند أعمار مبكرة وأوزان ثقيلة عند مقارنتها بغير المعاملة. وكذللك ارتفع معدل نمو الحملان

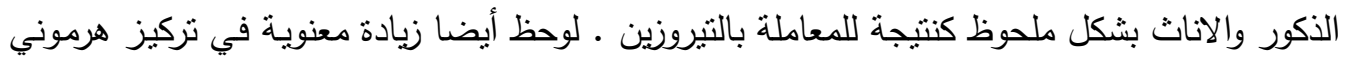
علاوة علاوة على ذلك كانت هنالك زيادة غير معنوية في حجم الخصيتين وكذلك في طول الزائدة الدودية كما

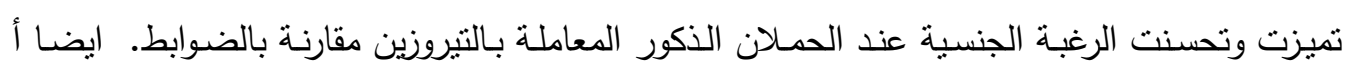

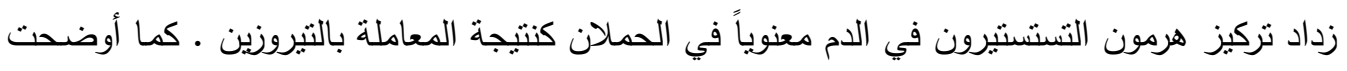

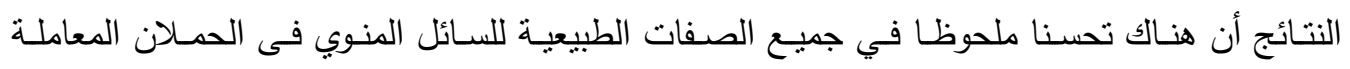
بالتيروزين مقارنة بالضوابط. وعليه فإن معاملة الحملان بالثيروزين كانت مصحوبة بعائد اقتصادى جيد . بالفورئ 